\title{
NARRATIVE REVIEW: METODE ANALISIS PRODUK VAKSIN YANG AMAN DAN HALAL BERDASARKAN PERSPEKTIF BIOTEKNOLOGI
}

\author{
Fitri Rahmi Fadhilah ${ }^{1}$, Firman Rezaldi ${ }^{2}$, M Fariz Fadillah ${ }^{3}$, \\ Muhammad Faizal Fathurohim ${ }^{4}$, Usman Setiawan ${ }^{5}$ \\ Institut Kesehatan Rajawali ${ }^{1}$, \\ Universitas Mathla'ul Anwar Banten 2,3,5 \\ Universitas Padjajaran Bandung ${ }^{4}$ \\ Korespondensi author: ffitrirahmi@gmail.com
}

\begin{abstract}
Biotechnology is the application of the branch of biology that involves other applied sciences in applying the principles of living things to produce goods and services, both conventional and modern. The application of biotechnological methods that are increasingly rapid, especially in the health and pharmaceutical fields, has a lot to fight for, especially in developing vaccines with healthy and halal criteria according to the biotech perspective. Halal status in the world of modern science has become a global issue, including the use of peptide-based vaccines. The results of the review show that a healthy and halal vaccine certainly has criteria, namely that it is safe to use, does not produce allergic reactions in the human body such as those made from horses or pigs. PCR is one of the molecular biology methods in the study of modern biotechnological methods which has a high level of sensitivity in detecting the content of pig DNA in various products, both medicinal and food.
\end{abstract}

Keywords: Biotechnology, Vaccines, Healthy and Halal

\begin{abstract}
Abstrak: Bioteknologi merupakan aplikasi dari cabang keilmuan biologi yang melibatkan sains terapan lainnya dalam menerapkan prinsip makhluk hidup untuk menghasilkan barang dan jasa baik yang diterapkan secara konvensional maupun modern.Penerapan metode bioteknologi yang semakin pesat terutama pada bidang kesehatan maupun farmasi banyak sekali yang harus diperjuangkan terutama dalam mengembangkan vaksin dengan kriteria sehat dan halal menurut cara pandang bioteknologi. Status halal dalam dunia sains modern ini telah menjadi isu global tak terkecuali pada pemanfaatan vaksin yang berbasis peptida. Tujuan dari review ini adalah mengkaji mengenai metode analisis produk vaksin halal dan sehat dalam kacamata bioteknologi. Vaksin yang sehat dan halal tentunya memiliki kriteria aman digunakan, tidak menghasilkan reaksi alergi pada tubuh manusia seperti yang terbuat dari hewan kuda maupun babi. PCR merupakan salah satu metode biologi molekuler dalam kajian metode bioteknologi modern yang memiliki tingkat sensitivitas tinggi dalam mendeteksi kandungan DNA babi pada berbagai produk baik obat maupun makanan.
\end{abstract}

Kata Kunci: Bioteknologi, Vaksin, Sehat, dan Halal 


\section{PENDAHULUAN}

Bioteknologi merupakan salah satu aplikasi sains terapan yang pada prinsipnya menggunakan makhluk hidup untuk menghasilkan produk dari jasa makhluk hidup. Bioteknologi terbagi menjadi dua kelompok utama yaitu bioteknologi konvensional dan modern.

Bioteknologi konvensional merupakan pemanfaatan makhluk hidup dalam menghasilkan barang dan jasa secara sederhana baik dari hulu maupun sampai hilir, sedangkan bioteknologi modern merupakan pemanfaatan makhluk hidup dalam menghasilkan barang dan jasa secara kompleks maupun dengan pemanfaatan teknologi makhluk hidup yang terkini. Teknik-teknik yang dibutuhkan dalam bioteknologi diantaranya adalah biokimia, mikrobiologi biologi sel, genetika, biologi molekuler, imunologi, teknik kimia dan informatika yang sudah meluas kajian nya menjadi Bioinformatika.

Bioinformatika merupakan kajian bioteknologi yang berbasis multidisipliner yang menghubungkan pendekatan biologi molekuler dan teknik informatika terutama dalam menghasilkan data-data biologi secara komputasi atau in silico yang diharapkan dapat memberikan model secara sistematis (Parikesit dkk., 2017). Bioteknologi jika dikaji dari sejarahnya terutama yang telah berkembang di Indonesia banyak terbukti pada produkproduk yang dihasilkan atas jasa makhluk hidup yaitu berupa keju, tempe, oncom yang merupakan contoh nyata dari sisi pangan dan berkhasiat dari sisi kesehatan (Wasilah et al., 2019).

Kajian bioteknologi khususnya pada level modern menuntut para peneliti untuk selalu menghasilkan penelitian-peneliitian yang berpotensi untuk diaplikasikan ke dalam sains terapan lainnya seperti pada bidang kedokteran, farmasi, pertanian, peternakan, pangan, gizi, perikanan, kelautan, bahkan lingkungan yang cenderung selalu rusak oleh cemaran-cemaran bahan kimia yang semakin sulit untuk dikendalikan. Penerapan metode bioteknologi yang semakin pesat terutama pada bidang kesehatan maupun farmasi banyak sekali yang harus diperjuangkan terutama dalam mengembangkan vaksin.

Vaksin merupakan makhluk hidup yang dilemahkan untuk menghasilkan kekebalan tubuh terhadap serangan penyakit baik kekebalan tubuh secara spesifik maupun non spesifik (Setiawan et al., 2012). Vaksin jika diklasifikasikan berdasarkan teknologi produksi nya terdiri dari vaksin hidup atau yang disebut sebagai live attenuated vaccine, vaksin inaktif (Killed vaccine), vaksin kombinasi, vaksin formula baru, vaksin subunit, vaksin rekombinan, dan vaksin polinukleotida. Penemuan vaksin merupakan pengembangan yang harus selalu dicapai dan berprioritas dalam bidang kesehatan. Hal tersebut ditandai dengan adanya pengaruh selama 20 tahun abad terakhir dimana penyakit dahulu secara umum telah ditemukan di dunia menjadi langka semenjak ditemukan nya vaksin.

Penemuan vaksin yang pertama adalah vaksin cacar. Vaksin tersebut telah dikembangkan oleh Edward Janner yaitu seorang dokter yang berasal dari Negara inggris. Penemuan yang telah berhasil diteliti menyatakan jika Seseorang yang minum susu dari sapi 
yang mengalami penyakit cacar, maka seseorang tersebut akan menghasilkan imunitas sehingga kebal terhadap penyakit cacar. Awalnya hal tersebut dapat terjadi ketika dalam penemuannya telah memanfaatkan eksudat dan sekresi dari sapi yang terkena cacar, dimana uji coba tersebut pun dilakukan pada anak laki-laki usia 8 tahun.

Penemuan vaksin cacar yang telah dikembangkan oleh Edward Janner kemudian diteruskan oleh Louis Paster yang diterapkan pada penyakit rabies. Keberhasilan dua ilmuan tadi membuat pemerintah mengesahkan undang-undang yang berisi wajib vaksin pada abad ke-19. Revolusi bidang kedokteran yang didukung dari sisi bioteknologi telah terbukti atas keberhasilan dalam mencegah penyakit polio dan campak.

Vaksin jika dikaji dari sejarahnya terutama pada jaman kuno banyak dikembangkan dari hewan-hewan yang pada dasarnya banyak merugikan manusia, baik dari sisi kesehatan maupun halalnya. Dalam kajian dasar bioteknologi maupun sudut pandang agama islam, agama ini selalu memprioritaskan hidup sehat yang diimbangi dengan cara halal menurut syariat yang sudah ditetapkan.

Vaksin yang sehat dan halal tentunya memiliki kriteria yaitu aman digunakan, tidak menghasilkan reaksi alergi pada tubuh manusia seperti yang terbuat dari hewan kuda maupun babi. Kandungan DNA babi pada produk vaksin, obat, kosmetik bahkan makanan yang sama sekali sudah dilarang oleh ajaran agama islam karena babi merupakan salah satu hewan yang tidak halal. Aplikasi bidang bioteknologi farmasi khususnya berupa sediaan vaksin diharapkan dapat memberikan pengaruh secara positif tehadap perkembangan industri farmasi baik yang dipertimbangkan terhadap sisi kesehatan maupun dalam sisi kehalalanya.

Pemanfaatan poduk bioteknologi farmasi terutama vaksin perlu menjadi prioritas akan status kehalalanya, karena pengembangan metode bioteknologi modern terkini menjadi alat untuk mengkonfirmasi mengenai kehalalan suatu produk yang dihasilkan. Kehalalan suatu produk dapat di uji melalui metode bioteknologi, baik pada metode PCR (Polymerase Chain Reaction) sebagai patokan atau gold standar maupun pada terapan PCR lainnya yang merupakan pengembangan dari PCR konvensional.

Dalam penggunaan bioteknologi modern memiliki banyak sisi kelebihan dalam melacak produk halal dibandingkan dengan PCR konvensional. Salah satu penggunaan bioteknologi modern adalah dengan cara screening menggunakan ELISA (Enzime Linked IMMUNOSORBANT ASSAYS). ELISA merupakan sebuah metode yang paling sering digunakan juga dalam mendeteksi kandungan DNA babi pada suatu produk baik obat, makanan, kosmetik, dan vaksin.

Berdasarkan latar belakang di atas, kami selaku penulis ingin membuat sebuah review artikel yang dapat membantu para akademisi maupun peneliti untuk memberikan informasi secara ilmiah mengenai metode analisis kriteria vaksin halal yang sesuai dengan kaidah Islam dan Ulama dari sisi bioteknologi. 


\section{METODE}

Metode yang digunakan pada kesempatan ini adalah studi literatur. Data yang dihasilkan berasal dari narasumber dalam bentuk jurnal, prosiding, dan konferensi. Hasil penelusuran lebih detail akan dilakukan secara manual tentunya pada suatu daftar pustaka yang mendukung maupun relevan pada pokok bahasan artikel ini.

Metode berbasis DNA umumnya memiliki sampel yang spesifik dan sensitif. Hal ini terjadi karena setiap spesies memiliki fragmen sekuan DNA yang conseve yang merupakan DNA penanda/marker. Dalam memeriksa sampel DNA diperlukan sebuah metode yang bernama PCR. Metode PCR adalah suatu metode enzimatis untuk amplifikasi DNA dengan cara in vitro. Pada proses PCR diperlukan beberapa komponen utama, yaitu DNA cetakan, Oligonukleotida primer, Deoksiribonukelotida trifosfat (dNTP), Enzim DNA Polimerase, dan Komponen pendukung lain adalah seperti senyawa buffer (Yusuf, 2010). Dengan menggunakan metode PCR, peniliti dapat mendeteksi DNA spesifik spesies tertentu seperti porcine (babi), bovine (sapi), ovine (domba) atau bahkan spesifik manusia.

Selain menggunakan PCR, terdapat juga metode ELISA untuk pengujian bahan DNA kandungan babi. Menurut Cahyaningsih, dkk (2019) tahapan Metode pengujian menggunakan Sandwhich ELISA sesuai prosedur standar pengujian kit komersial Porcine Detection Kits for Processed Meat (Biokits Neogen Corp, USA). Ekstraksi sampel dilakukan dengan menghomogenisasi $25 \mathrm{~g}$ sampel dengan $100 \mathrm{ml} \mathrm{NaCl}$ fisiologis, kemudian dipanaskan dengan cara direbus pada suhu $95-100{ }^{\circ} \mathrm{C}$ selama 15 menit lalu dibiarkan pada suhu ruang selama 15 menit.

Setelah itu, sampel disaring dan disentrifus kemudian diambil $100 \mu$ l lapisan bawah untuk uji lanjut menggunakan ELISA. Setiap pengujian ELISA selalu disertai kontrol positif dan kontrol negatif. Setiap sampel yang diuji ELISA dilakukan ulangan sebanyak 2 kali. Pembacaan hasil dilakukan dengan ELISA Reader pada panjang gelombang $450 \mathrm{~nm}$ dengan melihat nilai Optical Density (OD). Penentuan hasil uji positif atau negatif dilakukan dengan membandingkan nilai OD dan nilai cut off. Nilai cut off diperoleh dengan rumus:

\section{Cut off = Jumlah rerata kontrol negatif $\times 2.5$ (faktor pengali)}

\section{HASIL DAN PEMBAHASAN}

Surat Keputusan Lembaga Pengkajian Pangan, Obat-Obatan Dan Kosmetika Majelis Ulama Indonesia Nomor: Sk49/Dir/Lppom Mui/Xii/14 Tentang Kebijakan Analisa Laboratorium menyatakan bahwa beberapa produk termasuk sediaan obat dan eksipien yang digunakan dalam pembuatan obat wajib dilakukan analisa laboratorium dengan target uji berupa protein babi atau DNA babi atau residu etanol pada saat proses sertifikasi oleh LPPOM MUI.

Menurut Riaz dan Chaudry (2004) dalam pandangan islam segala sesuatu itu halal kecuali secara spesifik diharamkan oleh syariat. Tidak ada ayat-ayat al-qur'an ataupun hadist yang mengharamkan makanan hasil rekayasa genetika karena rekayasa genetika merupakan 


\section{IJMA: International Journal Mathla'ul Anwar of Halal Issues \\ Volume 1 Nomor 1- Maret 2021}

perkembangan terbaru dalam sians. Akan tetapi produk rekayasa genetika yang dihasilkan dari yang diharamkan tetap merupakan produk yang haram.

Terdapat tiga modifikasi yang menjadi perhatian utama dalam rekayasa genetika. Pertama perpindahan gen dari binatang ke tanaman atau dari tanaman ke binatang. Jika berasal dari hewan halal berarti halal namun jika berasal dari hewan haram berarti haram. Contoh salah satu kasus pada padi Nihonbare yang manggunakan sitokrom p450 babi berarti haram (Sagara, 2013). Kedua perpindahan gen dari serangga ke tanaman, asalkan tidak memicu pembentukan racun atau zat lain yang membahayakan berarti halal. Ketiga perpindahan gen dari hewan ke hewan, asalkan berasal dari hewan halal berarti halal asalkan tidak menimbulkan bahaya kesehatan, dan sebaliknya (Atma, dkk 2018).

Tabel 1. Standard Produk Pangan Halal Di Berbagai Negara (Kurniadi dan Ferdiansyah, 2016)

\begin{tabular}{|c|c|c|c|c|}
\hline Kategori & Indonesia & Malaysia & Thailand & Amerika \\
\hline Nomer & Fatwa MUI No.4/2003 & MS $1500 / 2009$ & THS $24000 / 2552$ & ISWA \\
\hline Mikrobia & $\begin{array}{l}\text { Halal, kecuali yang } \\
\text { menyebabkan racun, } \\
\text { menyebabkan } \\
\text { gangguan fungsi akal } \\
\text { dan raga, dan } \\
\text { berbahaya bagi } \\
\text { kesehatan, } \\
\text { tetapi ragi dari } \\
\text { manufaktur } \\
\text { bir/alhohol dapat } \\
\text { menjadi halal apabila } \\
\text { dicuci sampai bau, } \\
\text { rasa, dan warna } \\
\text { hilang. }\end{array}$ & $\begin{array}{l}\text { Halal, kecuali yang } \\
\text { menyebabkan racun, } \\
\text { menyebabkan } \\
\text { gangguan fungsi akal } \\
\text { dan raga, dan } \\
\text { berbahaya bagi } \\
\text { kesehatan. }\end{array}$ & $\begin{array}{l}\text { Halal, kecuali yang } \\
\text { menyebabkan racun, } \\
\text { menyebabkan } \\
\text { gangguan fungsi akal } \\
\text { dan raga, dan } \\
\text { berbahaya bagi } \\
\text { kesehatan, } \\
\text { tetapi ragi dari } \\
\text { manufaktur } \\
\text { bir/alhohol adalah } \\
\text { haram }\end{array}$ & $\begin{array}{l}\text { Halal, kecuali yang } \\
\text { menyebabkan racun, } \\
\text { menyebabkan } \\
\text { gangguan fungsi akal } \\
\text { dan raga, dan } \\
\text { berbahaya bagi } \\
\text { kesehatan. }\end{array}$ \\
\hline $\begin{array}{l}\text { Konsentrasi etanol } \\
\text { dinyatakan halal }\end{array}$ & $<1 \%$ & $\begin{array}{l}\text { Asal tidak } \\
\text { menyebabkan } \\
\text { "intoksikasi" }\end{array}$ & $<0.5 \%$ & $<0.05 \%$ \\
\hline $\begin{array}{l}\text { Tambahan } \\
\text { informasi }\end{array}$ & $\begin{array}{l}\text {-tape and air tape tidak } \\
\text { haram asal tidak } \\
\text { memabukkan } \\
\text {-etanol dari industry } \\
\text { alkohol haram } \\
\text {-Fuse oil dari khamir: } \\
\text { haram } \\
\text {-reaksi fuse oil secara } \\
\text { kimiawi menghasilkan } \\
\text { zat baru: halal } \\
\text {-cuka: halal }\end{array}$ & & & $\begin{array}{l}\text {-Cuka: halal } \\
\text {-yoghurt tanpa gelatin } \\
\text { dari babi:halal } \\
\text {-keju: halal }\end{array}$ \\
\hline Peraturan lain & $\begin{array}{l}\text { UU No. } 33 / 2014 \text { : } \\
\text { Jaminan produk halal }\end{array}$ & $\begin{array}{l}\text { MS 1514:2009: GMP; } \\
\text { MS 1480: 2007: } \\
\text { HACP }\end{array}$ & & $\begin{array}{l}\text { Codex alimentarius: } \\
\text { labelling of hallal food } \\
\text { CAC/GL-24-1997 }\end{array}$ \\
\hline
\end{tabular}

Kriteria Vaksin Halal dan Sehat dalam kacamata Bioteknologi

\section{Pendekatan Strategi Vaksin}

Berbagai pendekatan vaksin fokus pada berinteraksi dengan antigen presenting sel profesional seperti sel dendritik (DC) dalam menstimulasi imunitas seluler untuk pembersihan infeksi. Berbagai jenis vaksinasi dapat mempengaruhi pengolahan dan presentasi antigen serta imunitas seluler yang selanjutnya dihasilkan. Dalam jalur utama histocompatibility complex (MHC) kelas I, antigen sitosol dipecah menjadi peptida kecil melalui proteasome, kemudian dikenali oleh MHC kelas I dalam retikulum endoplasma (ER) dan dikirim ke permukaan sel untuk dipresentasikan ke CD8+ T sedangkan pada jalur MHC kelas II, antigen eksogen diendositasi menjadi vesikel, kemudian dikenali oleh MHC kelas II dalam endosomal / kompartemen lisosom dan dikirim ke permukaan sel untuk 
dipresentasikan ke CD4+ T. CD28 dan B7 adalah molekul co-stimulasi yang diperlukan untuk aktivasi sel T.

Strategi terapi yang berbeda telah dikembangkan termasuk vaksin berbasis vektor hidup, vaksin peptide- atau berbasis protein, vaksin berbasis asam nukleat, vaksin berbasis sel. Vaksin DNA menyalurkan DNA langsung ke inti DC, di mana DNA diekspresikan dan produk protein sitosol dipresentasikan MHC kelas I jalur untuk mengaktifkan sel CD8 + T. Vaksin berbasis RNA replicon, vaksin berbasis vektor bakteri dan vektor berbasis virus memberikan antigen target ke dalam sitosol untuk dipresentasikan MHC kelas I ke jalur sel $\mathrm{CD} 8+\mathrm{T}$. Vaksin berbasis peptida dapat memuat peptida antigenik ke molekul kelas I MHC untuk dipresentasikan ke sel CD8 $+\mathrm{T}$. Vaksin berbasis protein dapat memberikan protein eksogen dan biasanya mengaktifkan sel-sel helper (Barbara et al.,2010) \& (Kim et al., 2008) seperti CD4 + T.

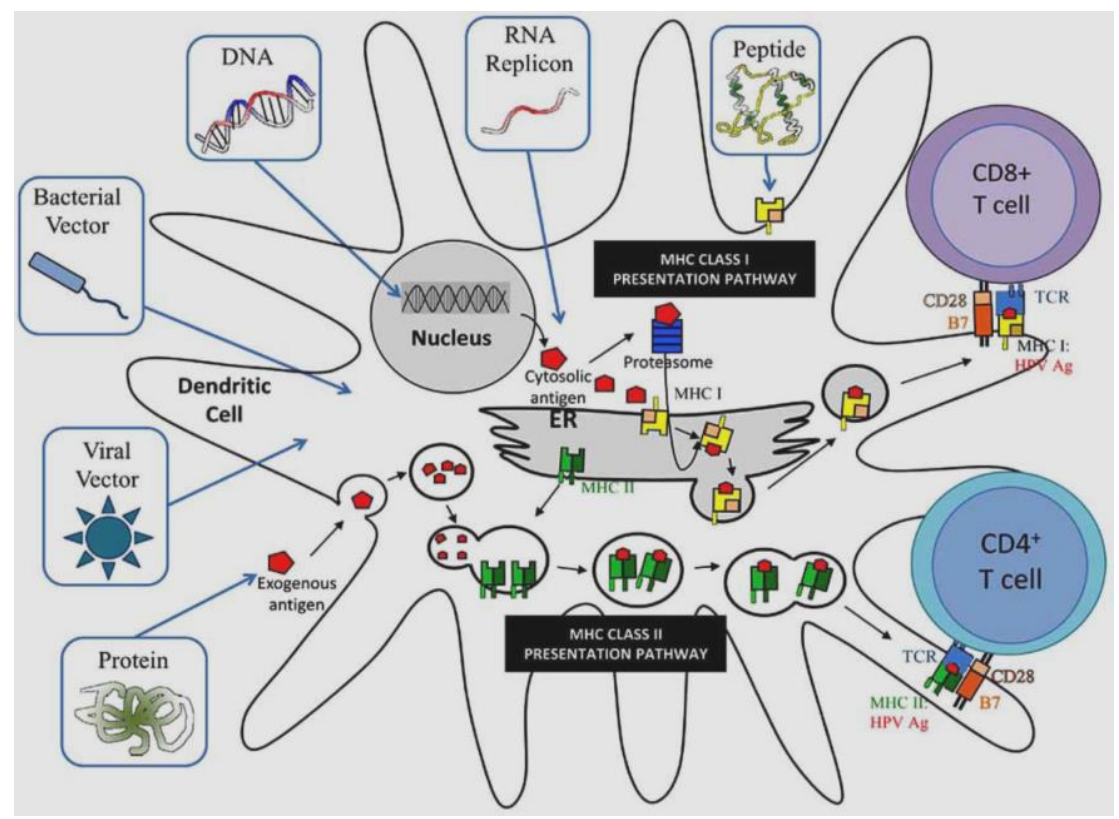

Gambar 1. Strategi Pendekatan Vaksin (Ma B, Xu Y, Fu-Hung C, Wu TC. 2010. HPV and Therapeutic Vaccines: Where are We in 2010? Current Cancer Therapy Reviews. 6: 81-103.)

\section{Live Vector-Based Vaccines}

Vaksin berbasis vektor hidup merupakan pendekatan yang menarik. Sifatnya imunogeniknya sangat kuat karena dapat bereplikasi dalam sel inang dan dapat memfasilitasi penyebaran antigen dari sel ke sel lain. Selain itu, vektor yang tersedia dapat disesuaikan atau direkayasa sesuai efek yang diinginkan. Hal ini telah dimanfaatkan dengan baik dalam konteks vaksin terapi HPV, di mana vektor hidup yang dimodifikasi untuk mengekspresikan HPV E6 dan / atau antigen E7 namun vektor virus hidup yang mampu merangsang antigenspesifik respon imun sel $\mathrm{T}$ sitotoksik namun kurang aman diberikan pada pasien dengan profil imumunodefisiensi. Vaksin jenis ini juga memiliki kapasitas terbatas untuk pemberian berulang karena induksi penetralan antibodi serta kemungkinan vektor yang sudah ada pada 
imunitas spesifik. Vaksin berbasis vektor hidup dapat dikategorikan ke dalam vektor bakteri dan vektor virus.

\section{a. Bacterial Vectors}

Vektor bakteri dapat disisipi gen yang diinginkan atau protein untuk antigenpresenting sel seperti dendritic cell. Contoh vektor bakteri yang digunakan dalam vaksin HPV terapi termasuk Lactococcus lactis, Lactobacillus plantarum, Salmonella enterica dan Listeria monocytogenes. Sejauh ini, vektor yang dihasilkan paling baik adalah Listeria monocytogenes. L.monocytogenes adalah bakteri gram positif yang mampu menghindar dari phagosomal lisis melalui sekresi dan replikasi listeriolysin O (LLO) dalam sitosol. Akibatnya, antigen dapat dipresentasikan oleh kedua kompleks (MHC) kelas I dan II untuk merangsang-antigen spesifik CD8 + dan CD4 + T-sel respon imun. Selain itu, karena sensitivitas dari L.monocytogenes terhadap antibiotik berarti dapat dengan mudah dimatikan jika menunjukkan gejala efek samping pada pasien. Percobaan pre-klinik L.monocytogenes yang mengkode protein fusi HPV-16 E7 baik ACTA (Lm-ACTA-E7) maupun fragmen LLO (Lm-LLOE7) dapat menginduksi CD8 + T-sel E7 secara spesifik (Sewel et al., 2004 ;2008).

\section{b. Viral Vectors}

Vektor virus adalah vektor untuk vaksin yang efektif untuk berbagai terapi. Ada banyak studi pre-klinik mengenai vektor virus hidup, seperti virus vaccinia, adenovirus, vesikular virus stomatitis (VSV) dan alphavirus. Salah satu vektor virus yang menarik adalah adenovirus. Suatu studi menemukan bahwa dengan menggunakan adenovirus untuk memberikan calreticulin dan HPV protein fusi E7 (Ad-CRT / E7) dapat melindungi tikus terhadap E7-pengekspresi tumor. Rechallenge dengan sel-sel tumor menunjukkan bahwa tikus dapat merangsang memori imunologi terhadap TC-1 sel yang dapat mengekspresikan E7 (Gomez et al., 2007).

Penelitian terbaru juga menunjukkan bahwa virus stomatitis vesikuler (VSV) berfungsi sebagai vektor efektif untuk antigen HPV. Uji klinis telah difokuskan pada virus vaccinia sebagai virus vektor karena efisiensi tinggi dan genomnya banyak. Salah satu kandidat vaksin HPV terapeutik TA-HPV, virus vaccinia rekombinan mengekspresikan HPV-16/18 E6 dan E7. TA-HPV pertama kali dievaluasi dalam Tahap I / II sidang pada 8 pasien dengan terapi-responsif lates tage kanker serviks. Pasien divaksinasi dengan satu dosis ( 2 x 106 PFU) dari TA-HPV menggunakan teknik skarifikasi. 3 dari 8 pasien terdeteksi menghasilkan antibodi spesifik E7- HPV 18 dan dan 1 dari 3 pasien yang dievaluasi terdeteksi adanya sel CD8 + T-HPV yang menunjukkan bahwa TA-HPV mampu memunculkan respon imun (Borysiewicz et al., 1996).

\section{Peptide-Based Vaccine}

Vaksinasi terapi HPV berbasis peptida melibatkan penyaluran langsung peptida yang berasal dari antigen HPV untuk diikat oleh DC (lihat Gambar. (1)). Vaksin peptida ini mudah dihasilkan, stabil dan aman, namun imunogenisitasnya rendah, selain itu vaksin peptida ini dapat terhambat oleh polimorfik sifat molekul antigen leukosit manusia (HLA) 
yang menunjukkan perlunya mengidentifikasi epitop imunogenik spesifik antigen HPV bagi banyak haplotipe HLA yang berbeda, serta menyebabkan sulitnya untuk menghasilkan vaksin berbasis peptida yang dapat mengobati keseluruhan populasi dari pasien, sehingga tidak praktis untuk vaksinasi untuk treatment skala besar. Akan tetapi jika pola epitop berhasil ditemukan, peluang untuk mengontrol epitop peptida yang terkandung di dalam vaksin sangat mungkin. Hal ini memiliki implikasi bahwa rekayasa vaksin peptida yang mengandung peptida imunogenik atau peptida dapat mengarahkan langsung ke target CD4 + T-helper atau CD8 + sitotoksik respon imun.

Pengembangan vaksin peptida untuk kanker serviks menjadi memungkinkan dengan adanya identifikasi berbagai MHC spesifik + CD4 dan CD8 + T epitop sel HPV protein awal seperti murine (H-2dB) dan manusia (HLAA.2). Studi preklinis telah difokuskan dengan meningkatkan imunogenisitas peptida vaksin melalui penggunaan bahan adjuvan atau tambahan seperti 4-1BB ligan ${ }^{16,} \mathrm{CpG}$ oligodeoxynucelotide, dan toksin mutan kolera untuk meningkatkan potensi vaksin. Strategi potensial lain untuk meningkatkan potensi vaksin peptida lainnya yaitu dengan melakukan identifikasi epitop untuk meningkatkan afinitas peptida terhadap MHC molekul dan peptida lipid (lipopeptides).

Vaksin terapi HPV berbasis peptida yang ditemukan sifatnya aman dan mampu ditoleransi dengan baik pada tahap awal klinis percobaan (Steller et al., 1998). Dalam fase non-random fase I dengan dosis meningkat, 12 pasien positif HLA-A2 dengan HPV-16berulang positif atau kanker leher rahim refrakter divaksinasi dengan lipopeptide terdiri dari HLA-A*0201-lipidated HPV-16 E7 peptida terkait dengan PADRE, peptida tambahan nonspesifik. Vaksin lipopeptide ini menimbulkan efek samping yang tidak signifikan, 5 dari 7 pasien yang menerima vaksinasi menunjukkan respon imun yang dihasilkan E7-spesifik sitotoksik limfosit T. Secara keseluruhan, vaksin berbasis peptida ini telah ditemukan ditoleransi dengan baik tetapi hanya dihasilkan terdeteksi respon klinis pada individu imunokompeten dengan penyakit pre invasive (Steller et al., 1998).

\section{Protein-Based Vaccine}

Vaksin berbasis protein memiliki beberapa keuntungan untuk pengembangan vaksin yaitu lebih aman dibandingkan dengan vaksin berbasis live-vektor. Selain itu, dapat mengatasi keterbatasan spesifitas MHC terkait dengan vaksin peptida. Protein mengandung semua kemungkinan epitop HLA dan dapat diproses menjadi epitop peptida oleh sel-sel pasien sendiri, namun seperti vaksin peptida, vaksin protein juga memiliki imunogenisitas yang rendah. Penekanan lain untuk pengembangan vaksin berbasis protein adalah bahwa protein dapat menghasilkan respon antibodi lebih baik daripada respon CTL. Akan tetapi karena protein disalurkan secara eksogen, protein memiliki keterbatasan dalam menghasilkan respon $\mathrm{T}$ sitotoksik limfosit (CTL). Uji praklinis telah menunjukkan bahwa penggunaan bahan tambahan, seperti liposom-polycation-DNA (LPD) atau ISCOMATRIX saponinbased dan fusi dengan molekul imunostimulan lainnya yang bertanggung jawab untuk penargetan antigen ke sel antigen-presenting (APC), dapat meningkatkan respon CTL. 
Contohnya termasuk protein fusi HPV-16 E7 dengan protein bakteri seperti Bordetella pertussis adenilat siklase (CyaA), yang menargetkan DC melalui interaksi dengan $\square \mathrm{M} ß 2$ integrin untuk menginduksi E7-spesifik respon CTL, atau Mycobacteria heat shock protein (HSP), yang meningkatkan respon CTL dan menghambat angiogenesis pada tumor Fusion HPV-16 E7 yang direstriksi Pseudomonas aeruginosa eksotoksin A, dapat meningkatkan translokasi protein MHC kelas I, juga dapat meningkatkan E7-spesifik T-sel dan respon antibody (Liao et al., 2005).

\section{DNA Vaccine}

Vaksin DNA merupakan salah satu pendekatan vaksinasi yang menarik karena vaksin DNA tidak menimbulkan respon anti-vektor pada pasien yang divaksinasi, memiliki kapasitas untuk pemberian berulang yang mungkin diperlukan untuk mencapai dan mempertahankan respon imun sasaran. Vaksin DNA juga sederhana, aman dan stabil dan mudah untuk diproduksi dalam skala besar. Vaksin DNA mampu memberikan proses pemberian protein antigenik yang berkelanjutan sehingga dapat meningkatkan memori imunologi, selain itu juga dapat direkayasa dalam mengekspresikan peptida HPV antigenik atau protein dan memiliki berbagai metode delivering antigen, yang memungkinkan vaksin ini memberikan antigen HPV untuk APC dan membangkitkan kedua respon sel T-antigen spesifik CD4 + dan CD8 + secara in vivo, namun, vaksin DNA ini sifat imunogenisitasnya rendah karena memiliki keterbatasan spesifisitas terhadap untuk APC dan ketidakmampuan untuk memperkuat dan menyebar di antara sel-sel in vivo. Strategi untuk meningkatkan vaksin terapi HPV berbasis DNA lebih ditekankan pada penargetan DNA yang mengekspresikan antigen target ke DC untuk meningkatkan respon imun.

Mekanisme vaksin DNA dalam merangsang sistem imun adalah setelah plasmid DNA disuntikkan ke dalam jaringan maka plasmid DNA akan bereplikasi secara otonom dan memproduksi protein asing atau antigen yang dikode oleh gen vaksin. Antigen ini langsung dapat menstimulasi sel B yang kemudian dapat memproduksi antibodi terhadap antigen atau protein asing yang dikode oleh plasmid DNA. Sel yang mengandung antigen asing tersebut kemudian dapat bersifat sebagai sel penyaji antigen (antigen presenting cells), yang kemudian dapat melalui jalur-jalur tertentu, baik melalui jalur major histocompatibility complex (MHC) I pada sel CD8+T atau MHC II pada sel CD4+T, sehingga mengalami proses yang berbeda dalam merangsang sistem imunitas tubuh. Protein asing juga dapat langsung masuk ke dalam suatu sel penyaji lainnya misalnya sel dendritik, sehingga dengan demikian selain dapat merangsang sistem imun humoral juga dapat merangsang sistem imun selular. Karena proses pembentukan antigen oleh sel hospes setelah vaksinasi DNA menyerupai produksi antigen pada saat terinfeksi dengan mikroorganisme secara alamiah, maka respon imun yang terjadi akibat vaksinasi DNA sama dengan respon imun yang diinduksi oleh mikroorganisme patogen (Radji, 2009). 


\section{IJMA: International Journal Mathla'ul Anwar of Halal Issues \\ Volume 1 Nomor 1- Maret 2021}

\section{RNA Replicon Based Vaccine}

Vaksin berbasis replicon RNA memanfaatkan molekul RNA, replikon RNA diistilahkan yaitu dapat mereplikasi dirinya sendiri. Vaksin ini dapat diberikan sebagai RNA atau DNA, yang ditranskripsi oleh sel ke replikon RNA. Replikon RNA dapat berasal dari alphavirus, seperti Venezuela Equine Encephalitis, Semliki Forest virus dan Sindbis virus dan dapat mereplikasi dalam berbagai sel, yang memungkinkan dapat menghasilkan lebih banyak protein daripada vaksin DNA konvensional. Kurangnya struktur gen mencegah pembentukan partikel virus dan penetral antibodi terhadap kapsid virus, sehingga memungkinkan pemberian berulang. Selain itu, RNA replikon memotong risiko integrasi dengan genom inang dan transformasi seluler terkait dengan vaksin DNA. Namun, ketidakstabilan RNA dibandingkan dengan DNA menyebabkan kesulitan dalam terjemahan klinis vaksin. Model praklinis telah berusaha untuk mengatasi kelemahan ini dengan menggabungkan stabilitas DNA dengan ekspresi antigen yang dikodekan oleh replikon RNA.

Prinsip dari vaksin ini yaitu DNA 'bunuh diri', yang ditranskripsi menjadi RNA replikon yang akan diekspresikan oleh antigen. Karena sel-sel yang terinfeksi dengan DNA bunuh diri akhirnya menjalani apoptosis, tidak ada kekhawatiran untuk integrasi genom atau transformasi seluler. Hsu et al. menunjukkan bahwa penggunaan vektor DNA 'bunuh diri' menghasilkan antigen HPV yang menimbulkan respon imun CD8 + T-sel tertentu dan antitumor efek pada tikus yang divaksinasi dengan HPV DNA bunuh diri. Namun, karena sifat bunuh diri ini, menyebabkan imunogenisitasnya rendah karena sel-sel yang terinfeksi, seperti DC gen pengiriman senjata, mengalami apoptosis. Fusion of E7 dengan BCL-xL, protein antiapoptotik, disampaikan oleh pSCA1, yang bunuh diri. Vektor DNA, meningkatkan imunogenisitas dengan meningkatkan antigen menyajikan kelangsungan hidup sel. The pSCA1 encoding E7 terkait untuk BCL-xL menghasilkan kuat CD8-E7 spesifik + T-sel kekebalan tubuh tanggapan dan efek antitumor dari pengkodean pSCA1 wild type $\mathrm{E} 7$ (Kim et al., 2004).

\section{Dendritic Based Vaccine}

Penggunaan vaksin terapi berbasis DC dapat berpotensi menargetkan HPV yang terasosiasi dengan kanker. Vaksin berbasis sel dendritik ini dibuat dengan memasukan DC dengan antigen virus secara in vitro dan menginjeksikannya kepada pasien. Jalur yang dapat diintroduksikan yaitu melalui MHC kelas I dan kelas II pada DC dengan antigen peptida atau protein, atau dengan DNA virus atau RNA. Reintroduksi DC yang sudah matang memungkinkan untuk presentasi antigen yang lebih efektif dan dengan demikian respon imun yang lebih kuat. Namun, vaksin ini tergolong mahal dan sulit untuk menghasilkan pada skala besar karena sifatnya autolog. Teknik kultur variannya pun dapat menyebabkan tidak konsisten dalam efikasi vaksin dan kurangnya standar dalam evaluasi vaksin. Lebih lanjut lagi, karena antigen DC harus kembali ke limfoid tempat organ sel-sel $\mathrm{T}$ naif berada, targeting sangat penting untuk memaksimalkan efikasi dari vaksin berbasis DC. Model 
praklinis telah mencoba untuk menentukan optimal kondisi untuk persiapan dan penargetan vaksin berbasis DC.

Pemuatan efektif antigen tumor kepada DC dapat dicapai melalui pengiriman gen ke DC dengan menargetkan adenoviral vektor ke CD40 dengan antibodi bispecific ${ }^{22}$. DC ini dapat diinjeksikan melalui intramuskular, subkutan, atau rute intravena. Injeksi melalui intramuskular telah terbukti menghasilkan respon imun adaptif E7 khusus paling ampuh dan efek anti-tumor terbesar. Sebagai contoh, dalam Tahap I percobaan pada 10 pasien dengan Tahap Ib atau IIa kanker serviks, subkutan suntikan DC autologus berdenyut dengan HPV16/18 protein E7 dan lubang kunci limpet hemocyanin (KLH) tanggapan-antigen spesifik elisitasi, menunjukkan peningkatan yang signifikan dalam respon sel CD4 + T E7 khusus dalam semua sepuluh divaksinasi pasien dan E7-spesifik respon sel CD8 $+\mathrm{T}$ dalam enam dari sepuluh pasien (Santin et al., 2008).

\section{Tumor Cell-Based}

Melalui rekayasain vitro, imunogenisitas sel-sel tumor dapat ditingkatkan dengan mengekspresikan protein imunomodulator, terutama sitokin seperti IL-2, IL-12 dan GMCSF. Karena vaksin berbasis sel tumor tidak memerlukan identifikasi yang jelas dari antigen tumor, vaksin ini lebih berguna untuk kanker tanpa tumor specifik antigen dari kanker serviks yang antigennya sudah diketahui. Beberapa vaksin HPV berbasis sel tumor telah diuji dalam model praklinis. Vaksinasi tikus dengan iradiasi sel tumor E6 / E7 positif mengekspresikan IL-12 secara signifikan dalam penurunan ukuran lesi E6 / E7-pengekspresi tumor (Indrova et al., 2006). Vaksin berbasis sel tumor autologous dan allogeneic telah diuji dalam uji klinis kanker lain seperti usus kanker, melanoma, dan kanker $\operatorname{prostat}^{25}$ namun belum ada uji klinis vaksin tersebut terhadap HPV. Selain itu, vaksin berbasis tumor kemungkinan besar tidak akan digunakan dalam HPV terkait lesi prekursor. Untuk pasien HPV relatif sehat dengan neoplasia ringan, risiko untuk berubah menjadi kanker melalui vaksin berbasis sel tumor utama mungkin bisa terjadi. Selain itu, vaksin autologous ini tergolong mahal dan sulit untuk dihasilkan dalam skala besar. Dengan demikian, vaksin berbasis sel tumor ini tidak disarankan untuk terapi HPV.

Tabel 2. Karakteristik Berbagai Pendekatan Vaksin (Radji M. 2009. Vaksin DNA Vaksin Generasi Keempat. Majalah Ilmu Kefarmasian. Vol.VI, No. 1:28 - 37)

\begin{tabular}{|l|l|l|}
\hline \multicolumn{1}{|c|}{ Pendekatan Vaksin } & \multicolumn{1}{|c|}{ Kelebihan } & \multicolumn{1}{c|}{ Kelemahan } \\
\hline $\begin{array}{l}\text { Live-vector based } \\
\text { ( Bacterial vectors \& Viral } \\
\text { vectors) }\end{array}$ & $\begin{array}{l}\text { ・ Imunogenisitasnya tinggi } \\
\text { - Dapat memfasilitasi } \\
\text { penyebaran antigen dari sel ke } \\
\text { sel } \\
\text { Berbagai variasi vektor yang } \\
\text { tersedia }\end{array}$ & $\begin{array}{l}\text { Immunorejectionnya tinggi pada } \\
\text { pasien } \\
\text { Sulit diberikan secara berulang }\end{array}$ \\
\hline Peptide-based & Aman, stabil, mudah diproduksi & $\begin{array}{l}\text { Imunogenitas rendah, terhambat } \\
\text { oleh profil epitop HLA pasien } \\
\text { yang berbeda-beda. }\end{array}$ \\
\hline
\end{tabular}

Narrative Review: Metode Analisis Produk Vaksin yang Aman dan Halal Berdasarkan 


\section{IJMA: International Journal Mathla'ul Anwar of Halal Issues}

Volume 1 Nomor 1- Maret 2021

\begin{tabular}{|c|c|c|}
\hline Protein-based & Aman, stabil, mudah diproduksi & $\begin{array}{l}\text { Imunogenitas rendah } \\
\text { Butuh adjuvan atau tambahan } \\
\text { untuk meningkatkan respon } \\
\text { imun seluler. }\end{array}$ \\
\hline DNA-based & $\begin{array}{l}\text { Aman,stabil, mudah diproduksi } \\
\text { tidak menimbulkan } \\
\text { immunorejection pada pasien, } \\
\text { dapat diberikan secara berulang }\end{array}$ & $\begin{array}{l}\text { - Imunogenitas rendah } \\
\text { - Ketidakmampuan untuk } \\
\text { menstimulasi penyebaran } \\
\text { antigen secara in vivo } \\
\text { - Ada resiko integrasi ke dalam } \\
\text { genom atau transformasi seluler }\end{array}$ \\
\hline RNA Replicon-based & $\begin{array}{l}\text { - Tidak infeksius, tidak ada } \\
\text { resiko integrasi kromosom atau } \\
\text { transformasi sel. } \\
\text { - Mampu imunisasi diulang } \\
\text { - ekspresi antigen Peningkatan } \\
\text { - Berbagai variasi vektor yang } \\
\text { tersedia }\end{array}$ & $\begin{array}{l}\text { - Kurang stabil dibandingkan } \\
\text { dengan DNA } \\
\text { - Kesulitan dalam penyimpanan } \\
\text { jangka panjang } \\
\text { - Sulit diproduksi dalam skala } \\
\text { besar }\end{array}$ \\
\hline Dendritic cell-based & $\begin{array}{l}\text { - Imunogenisitas tinggi } \\
\text { menggunakan APC paling } \\
\text { ampuh } \\
\text { - Efisiensi presentasi antigen } \\
\text { - Beberapa metode pemuatan } \\
\text { Ag tersedia }\end{array}$ & $\begin{array}{l}\text { - Mahal } \\
\text { - kurangnya kriteria standar } \\
\text { untuk } \\
\text { kualitas vaksin karena sifat } \\
\text { autologous } \\
\text { - Sulit untuk diproduksi dalam } \\
\text { skala besar }\end{array}$ \\
\hline Tumor cell-based & $\begin{array}{l}\text { - Berguna jika antigen tumor } \\
\text { tidak diketahui } \\
\text { - Kemungkinan untuk } \\
\text { mengekspresikan antigen tumor } \\
\text { yang relevan } \\
\text { - Potensi dapat ditingkatkan } \\
\text { dengan treatment sitokin }\end{array}$ & $\begin{array}{l}\text { - Kurang aman, mahal } \\
\text { - Sulit diproduksi dalam skala } \\
\text { besar }\end{array}$ \\
\hline
\end{tabular}

PCR (Polymerase Chain Reaction) atau reaksi berantai polimerase adalah suatu metode enzimatis untuk memperbanyak secara eksponensial suatu sekuen nukleotida tertentu secara invitro. PCR pertama kali dikembangkan oleh Kary Mullis pada tahun 1985 seorang peneliti dari CETUS Corporation. PCR dapat melipatgandakan molekul DNA dan memisahkan gengen; kelebihan metode ini adalah suhu yang dapat tinggi dan rendah dengan cepat selain itu PCR juga bekerja dengan komponen yang jumlahnya sedikit (Fatchiyah, 2011).

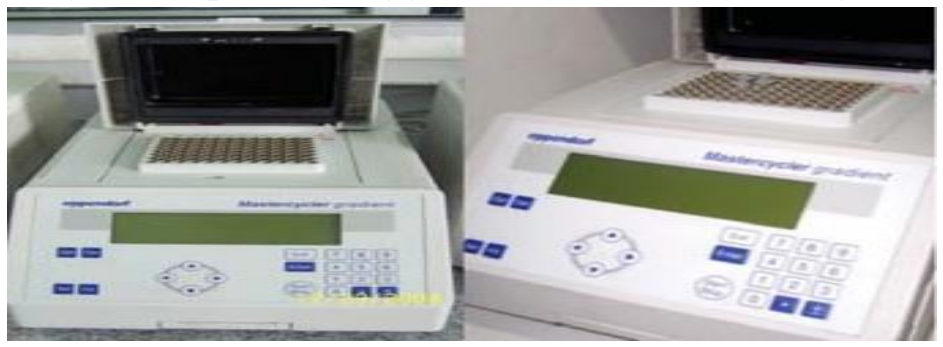

Gambar 2. Alat PCR (Polymerase Chain Reaction)

Narrative Review: Metode Analisis Produk Vaksin yang Aman dan Halal Berdasarkan 
(Sumber: Novel, SS dkk. Perbandingan Beberapa Metode Molekuler dalam Uji DNA HPV (Human Papillomavirus). 2011. CDK 186 (38):5)

Prinsip kerja PCR dan elektroforesis yaitu isolasi DNA sampel dari bahan klinis atau dari jaringan yang disimpan pada paraffin, proses amplifikasi DNA ang telah diisolasi; proses amplifikasi sendiri terbagi tiga tahapan yaitu denaturasi, annealing, dan elongasi. Tahapan denaturasi terjadi pada suhu $97^{\circ} \mathrm{C}$ ada proses ini terjadi denaturasi linearisasi DNA (Bartlett, 1999). Tahap kedua adalah penempelan primer atau annealing pada DNA target yang akandiperbanyak, membutuhkan suhu sekitar $55^{\circ} \mathrm{C}$. Tahap ketiga adalah elongasi (polimerisasi) membutuhkan suhu $72^{\circ} \mathrm{C}$ agar siklus polimerisasi lebih optimal (rown, 1995), hasil amplifikasi dideteksi menggunakan alat elektroforesis pada gel agarosa; teknik elektroforesis adalah teknik yang memisahkan molekumolekul fragmen DNA dalam sebuah medan listrik pada medium padat atau semi padat.

Hal yang diperlukan untuk PCR adalah primer oligonukleotida sintetik yang mengapit DNA target, DNA sampel yang bekerja sebagai cetakan pertama, polimerase DNA yang stabil pada suhu tinggi (polimerase Taq), deoksiribonukleotida (dATP, dGTP, dCTP dan dTTP) dan buffer yang mengandung $\mathrm{MgCl}_{2}$. Susunan primer merupakan salah satu kunci, apakah PCR ini berhasil atau gagal. Jika susunan primer benar akan menghasilkan amplifikasi fragmen yang dikehendaki. Apabila susunan primer tidak benar dapat tidak terjadi amplifikasi fragmen DNA atau terjadi amplifikasi fragmen DNA yang tidak spesifik. Penyusunan primer harus benar diperhatikan. Oligonukleotida yang digunakan paling tidak 16 nukleotida dan sebaiknya 20-24 nukleotida. Primer yang baik mempunyai susunan GC $40 \%$ - AT 60\% (Fatchiyah, 2011).

Metode PCR dan elektroforesis hanya digunakan untuk mendeteksi ada atau tidaknya DNA Pada contoh gambar 2. dapat dilihat nomor 1 s.d.11, nomor 1 dan 2 merupakan kontrol negatif dan kontrol positif genotipe HPV 16. Nomor 3-11 adalah sampel-sampel yang positif terinfeksi; ke-9 sampel menunjukkan sinyal yang sama dengan nomor 2, menunjukkan bahwa ke-9 sampel tersebut positif terinfeksi HPV, namun tidak cukup untuk menentukan genotipe HPV dalam setiap sampelnya.
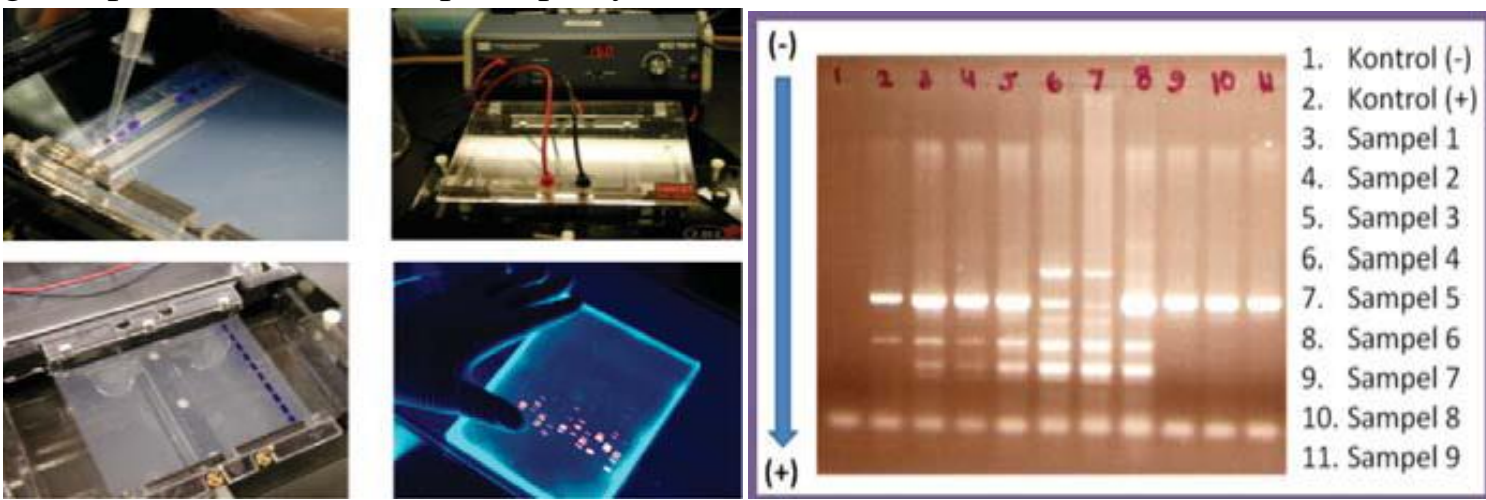

Gambar 3 Hasil amplifikasi yang dideteksi menggunakan PCR pada pemeriksaan infeksi HPV.m (Sumber: Novel, SS dkk. Perbandingan Beberapa Metode Molekuler dalam Uji DNA HPV (Human Papillomavirus). 2011. CDK 186 (38):5) 


\section{IJMA: International Journal Mathla'ul Anwar of Halal Issues \\ Volume 1 Nomor 1- Maret 2021}

ELISA (Enzyme-linked immunosorbent assay) atau nama lainnya enzyme immunoassay (EIA) merupakan teknik biokimia yang banyak digunakan di bidang imunologi untuk mendeteksi adanya antibody atau antigen pada suatu sampel. ELIS diperkenalkan pada tahun 1971 oleh Peter Perlmann dan Eva Engvall untuk menganalisis adanya interaksi antigen dengan antibodi di dalam suatu sampel dengan menggunakan enzim sebagai reporter label. Terdapat beberapa jenis teknik ELISA, yaitu (1) Indirect ELISA; (2) Direct ELISA; (3) ELISA Sandwich; (4) ELISA Multiplex dan (5) ELISA Biotin Streptavidin.

Dalam penggunaan sehari-hari ELISA bisa digunakan unruk melabel suatu antigen atau mengetahui antibody yang ada dalam tubuh. Apabila kita ingin mengetahui antigen apa yang ada di dalam tubuh, maka yang diendapkan adalah antibodynya, begitu pula sebaliknya. Untuk mendeteksi kadar suatu protein, maka dapat digunakan teknik ELISA sandwich assay dengan dengan mengedapkan antibody pada well plate.

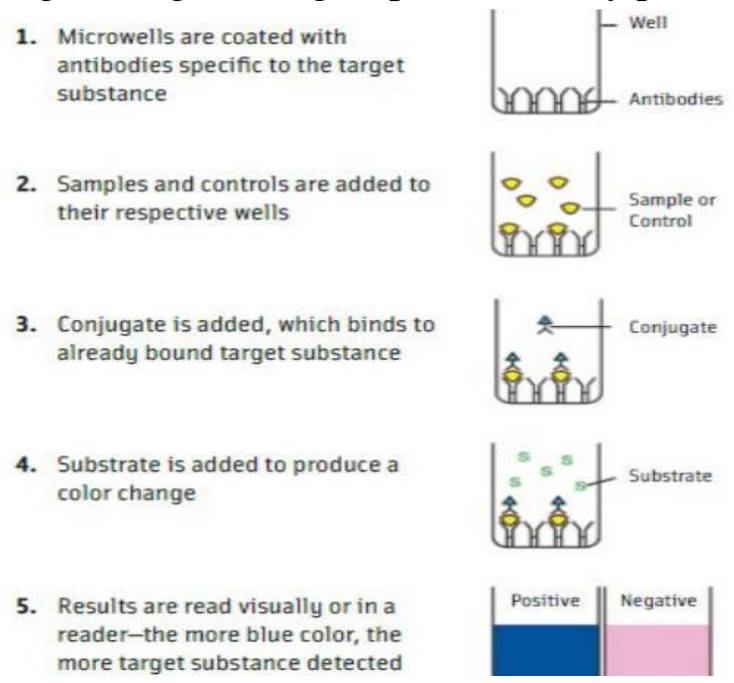

Gambar 4. Prinsip metode ELISA sandwich untuk memeriksa kadar protein sampel

Fungsi dari test ELISA yaitu bukan hanya untuk mengetahui keberadaan suatu antigen dengan antibodi tetapi juga untuk mengukur kadar antigen atau antibodi tersebut dengan menggunakan alat spektrofotometer. Spektrofotometer adalah sebuah alat yang dapat mengukur jumlah dari cahaya yang menembus sumuran dari microplate. Kompleks antigen-antibodi yang terjadi pada well mcroplate dan setelah pemberian substrat, enzim yang terikat pada antibody ke dua pada kompleks antigen-antibodi yang terbentuk akan memberikan perubahan warna pada cairan tersebut, sehingga akan memberikan optical density yang berbeda. Optical density dapat dinyatakan meningkat atau menurun berdasarkan pengenceran material standart, sehingga akan menghasilkan kurva dose-response yang nantinya akan digunakan untuk mengestimasi kadar protein tersebut.(Johnson et al., 2007). 


\section{KESIMPULAN}

Pemanfaatan produk bioteknologi farmasi terutama vaksin perlu menjadi prioritas akan status kehalalan produk tersebut. Untuk menguji suatu produk halal berdasarkan ilmu bioteknologi dapat menggunakan metode PCR.

\section{DAFTAR PUSTAKA}

Atma. Y., Taufik. M., dan Seftiono. H. 2018. Identifikasi Resiko Titik Kritis Kehalalan Produk Pangan: Studi Produk Bioteknologi. Jurnal Teknologi Vol 10, No 1. Hal 61 66.

Borysiewicz LK, Fiander A, Nimako M, et al. 1996. A recombinant vaccinia virus encoding human papillomavirus types 16 and 18, E6 and E7 proteins as immunotherapy for cervical cancer. Lancet; 347: 1523-7.

Brown D.R., Fan L., Jones J., and Bryan J., 1995. Colocalization of Human Papillomavirus Type $11 \mathrm{E} 1^{\wedge} \mathrm{E} 4$ and L1 Proteins in Human Foreskin Smoking. J. Nat. Canc. Inst. Monogr. 31: 20 - 28.

Cahyaningsih, D., Latif, H., dan Sudarnika, E. 2019. Identifikasi Penambahan Daging Babi pada Pangan Berbahan Dasar Daging Sapi Menggunakan ELISA dan qPCR. Acta Veterinaria Indonesia, Vol 7, No. 2.

De Gruijl TD, van den Eertwegh AJ, Pinedo HM, Scheper RJ. 2008. Whole-cell cancer vaccination: from autologous to allogeneic tumor-and dendritic cell based vaccines. Cancer Immunol Immunother. 57: 1569-77.

Fatchiyah, Arumingtyas L, Widyarti S, Rahayu S, 2011. Biologi Molekular. Jakarta: Erlangga.

Gomez-Gutierrez JG, Elpek KG, Montes de Oca-Luna R, Shirwan H, Sam Zhou H, McMasters KM. 2007. Vaccination with an adenoviral vector expressing calreticulinhuman papillomavirus $16 \mathrm{E} 7$ fusion protein eradicates E7 expressing established tumors in mice. Cancer Immunol Immunother. 56: 997-1007.

Johnson AM, Merlini G, Sheldon J \& Ichihara K. 2007. Clinical indications for plasma protein assays: transthyretin (prealbumin) in inflammation and malnutrition1) International Federation of Clinical Chemistry and Laboratory Medicine (IFCC) IFCC Scientific Division Committee on Plasma Proteins (CPP). Clin Chem Lab Med 2007;45(3):419-426. by Walter de Gruyter . Berlin . New York. DOI 10.1515/CCLM.2007.051.

Indrova M, Bieblova J, Jandlova T, Vonka V, Pajtasz-Piasecka E, Reinis M. 2006 Chemotherapy, IL-12 gene therapy and combined adjuvant therapy of HPV 16associated MHC class I- proficient and-deficient tumours. Int J Oncol. 28: 253-9.

Kim D, Gambhira R, Karanam B, Monie A, Hung CF, Roden R, Wu TC. 2008.

Generation and characterization of a preventive and therapeutic HPV D NA vaccine. 
Vaccine. 26: 351-60.

Kim TW, Hung CF, Juang J, He L, Hardwick JM, Wu TC. 2004. Enhancement of suicidal DNA vaccine potency by delaying suicidal DNA-induced cell death. Gene Ther. 11: 336-42.

Kurniadi, M dan Frediansyah, A. 2016. Perspektif Halal Produk Pangan Berbasis Bioproses Mikrobia. Jurnal Reaktor Vol 16, No. 3.

Liao CW, Chen CA, Lee CN, et al, 2005. Fusion protein vaccine by domains of bacterial exotoxin linked with a tumor antigen generates potent immunologic responses and antitumor effects. Cancer Res. 65: 9089-98

Ma B, Xu Y, Fu-Hung C, Wu TC. 2010. HPV and Therapeutic Vaccines: Where are We in 2010? Current Cancer Therapy Reviews. 6: 81-103

Novel S.S, Safitri R, Hatijanto SH, Nuswantara S, Perbandingan Beberapa Metode Molekuler dalam Uji DNA HPV (Human Papillomavirus). 2011. CDK 186 (38):5

Parikesit, A. A., \& Anurogo, D. (2017). Pemanfaatan bioinformatika dalam bidang pertanian dan kesehatan. Review. Vol 85 (2), 105 - 115. http:dx.doi.org/ 10.22302/iribb. Jur.mp.8v5i2.257.

Radji M. 2009. Vaksin DNA: Vaksin Generasi Keempat. Majalah Ilmu Kefarmasian Vol.VI, No. 1:28 - 37.

Sagara B. 2013. Industri Pangan Halal. https://www.scribd.com. e-book.

Santin AD, Bellone S, Palmieri M, et al. 2008. Human papillomavirus type 16 and 18 E7-pulsed dendritic cell vaccination of stage IB or IIA cervical cancer patients: a phase I escalating-dose trial. J Virol. 82: 1968-79.

Setiawan, R. B. (2012). Efektivitas Vaksin Dari Bakteri Mycobacterium Fortuitum Yang Diinaktivasi Dengan Pemanasan Untuk Pencegahan Penyakit Mycobacteriosis Pada Ikan Gurami (Osphronemus Gouramy). Jurnal Perikanan Kelautan, 3(1).

Sewell DA, Douven D, Pan ZK, Rodriguez A, Paterson Y. 2004. Regression of HPVpositive tumors treated with a new Listeria monocytogenes vaccine. Arch Otolaryngol Head Neck Surg. 130: 92-7.

Sewell DA, Pan ZK, Paterson Y. 2008. Listeria-based HPV-16 E7 vaccines limit autochthonous tumor growth in a transgenic mouse model for HPV-16 transformed tumors. Vaccine. 26: 5315-20.

Steller MA, Gurski KJ, Murakami M, et al. 1998. Cell-mediated immunological responses in cervical and vaginal cancer patients immunized with a lipidated epitope of human papillomavirus type 16 E7. Clin Cancer Res. 4: 2103-9.

Surat Keputusan Lembaga Pengkajian Pangan, Obat-obatan dan Kosmetika Majelis Ulama Indonesia Nomor: SK49/Dir/LPPOM MUI/XII/14 Tentang Kebijakan Analisa Laboratorium. 1 - 4 .

Tillman BW, Hayes TL, DeGruij1 TD, Douglas JT, Curiel DT. 2000. Adenoviral vectors targeted to CD40 enhance the efficacy of dendritic cell- based vaccination 


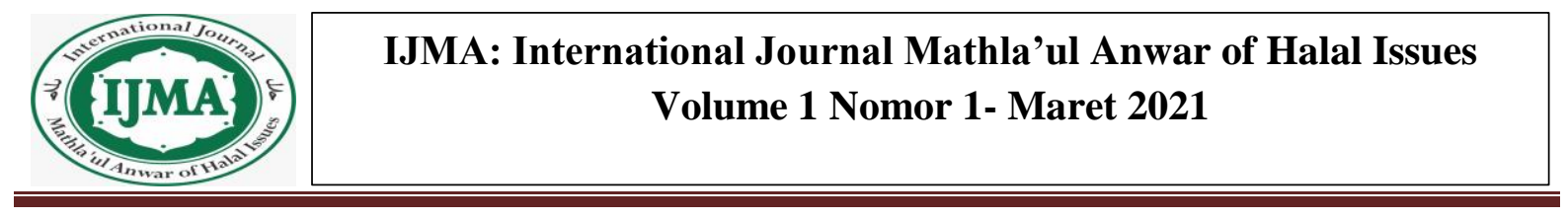

against human papillomavirus 16-induced tumor cells in a murine model. Cancer Res. 60: 5456-63.

Wasilah, U., Rohimah, S., \& Su'udi, M.(2019).Perkembangan Bioteknologi di Indonesia. Rekayasa, 12(2), 85-90.

Yusuf. Z. K. 2010. Polymerase Chain Reaction. Saintek Vol. 5, No. 6. Hal 1-6. 